dr Dario Šimičević, dr Snežana Štetić

College of Tourism, Belgrade

UDK 338.486.41:005.962

005.42-024.61

\title{
THE ROLE AND IMPORTANCE OF INTERNSHIP PROGRAMS AS PART OF FORMAL EDUCATION: STUDENTS' PERCEPTIONS - THE CASE OF COLLEGE OF TOURISM
}

\begin{abstract}
As one of the fastest growing industries tourism is in increasing need for well educated and skillful employees on both operational and managerial level. Institutions of higher education are requested by tourism industry to produce quality human resources able to respond immediately to their needs and to be involved in working processes as fast as possible with low or without any additional costs for future employees' initial job training. With inclusion of training and internship programs into, primarily vocational, but also, into bachelor studies students will be trained for their future jobs through real business situations and environment.

This paper focuses on students' perceptions of internship and training programs as
\end{abstract}

\section{Introduction}

Tourism industry offers great opportunities for employment of different profiles of the workers. Tourism is "a labour-intensive service industry, dependent for survival on the availability of good quality personnel to deliver, operate, and manage the tourist product" (Amoah and Baum, 1997) and it is expected that it will continue to be in future. The reason for this lies in fact that tourism is based upon successful communication between service providers and service users. (Štetić and Simičević, 2013) Needs for specific knowledge and skills of employees in tourism as respond to different requests and need of participant in various forms of tourism are triggering development and multiplication of educational programs worldwide, including Serbia. Also, tour- part of their formal education. Through anal$y$ sis of the survey distributed among students of the College of Tourism it will be shown how students perceive the internship programs and importance of these programs for their future employment. Also, it will be shown the level of their satisfaction with tourism companies where they are performing internship programs and the level of their satisfaction with activities of the College of Tourism in communications during the internship, program management and implementation of the internship programs.

Key words: education, tourism, internship programs, formal education, student experience

ism industry is globalized and operates on international level, employees are facing to work with people from all around the World and managerial skills, knowledge and environment are influenced by tourism globalization. (Hjalager, 2003) Globalization of tourism influences operational workers as well requesting from them to have vast operational, social and communicational skills. In such environment employers are turning to higher education institutions as a source of quality, theoretically educated and skillful in practical knowledge employees. (Spowart, 2011; Hjalager, 2003)

Human resources in tourism should be considered as multidimensional category. (Štetić and Šimičević, 2013) In regard to this, Amoah and Baum (2003) are emphasizing the understanding of the image of employer, availability and quality of skilled workers, 
reward system, production or creation of new value by employees, working conditions and working hours, engagement of the workforce across national borders etc. In order to create a basis for a successful business in tourism, bearing in mind the complexity and multidimensionality of human resources in tourism, in addition to equipment and facilities (company hardware) it is necessary to acknowledge employees, their attitudes, knowledge, abilities, skills and readiness to act. (Lam, Xiao, 2000) Thurow emphasizes that knowledge and skills of employees will be the key for competitive advantage in $21^{\text {st }}$ century (Juran, Godfrey and Blanton, 1999)

Need for new skills and knowledge in tourism have become a constant need as result of dynamic relations established on the tourist market and the tourism industry is aware of these needs. (Štetić and Simičević, 2013) Numerous programs of education for tourism could be divided in two main categories: programs of formal education (provided by institutions of higher education) and informal programs (provided by tourism industry companies). However, we should consider these programs integrally and it is necessary to work on linking of educational institutions and businesses in order to create an integrated system of education which will link formal and informal programs (HorngHuey and Mojdeh, 2014). Best ways for integration of formal and informal programs of education for tourism are internship programs emphasizing practical skills (Lam and Ching, 2007) necessary for employees in tourism industry, on managerial and operational level. Internship programs are referred to as "short-term periods of practical work" (Zopiatis and Theocharous, 2013; Koc et al., 2014), "work integrated learning model" ( $R u$ hanen, Robinson and Breakey, 2013) or WIL, "on-the-job training" (Sevillia et al., 2014), "structured, supervised and well-timed activities and tourism workplace-based experiences" (Mekawy and Abu Bakr, 2014), "experiential exercises" (Horng-Huey and Mojdeh, 2014 ) etc. One of commonly used and cited definitions of internship in tourism is one by Zopiatis where internship experience describes as "a structured and career-relevant supervised professional work/learning experience, paid or unpaid, within an approved hospitality agency/organization/corporation, under the direct supervision of at least one practicing hospitality professional and one faculty member, for which a hospitality student can earn academic credit" (Zopiatis and Theocharous, 2013).

As one more comprehensive and simpler definition we could use this one where internship in tourism is paid or unpaid work in one of tourism related companies where students are acquiring some professionally relevant practical skills and applying previously learned theoretical knowledge under professional supervision. As stated in definition it is important to have professional supervision over student's work. This way internship has three parties or three stakeholders interested in internship programs: students, institutions and industry partners (Lam and Ching, 2007; Yafang and Gongyong, 2008; Chen and Shen, 2012). Cooperation between stakeholders on every step of internship is required in order to achieve best possible results for each of the stakeholders.

\section{Literature review}

No matter which of the above terms we use to describe internship several important questions or aspects arises when we talk about the research of internship as part of formal education. There are three groups or stakeholders interested in internship programs and we must take in consideration tourism industry needs and expectations (Zopiatis and Theocharous, 2013; Donina and Luka, 2014; Sevillia et al., 2014), higher education institutions' views and goals (Lam and Ching, 2007; Ruhanen, Robinson and Breakey, 2013; Mekawy and Abu Bakr, 2014; Hjalager, 2003) and students perceptions and motives when it comes to internship programs (Koc et al., 2014; Hughes, Mylonas and Benckendorff, 2013; Pang, 2010; Yafang and Gongyong, 2008). 
Three partite relations between tourism industry, institutions of higher education and students are established in order to avoid or overcome possible gaps produced by different needs and expectations of each party (Lam and Ching, 2007; Donina and Luka, 2014). As a potential source of the gaps Dale and Robinson (2001) are emphasizing the dilemma should tourism education institutions enable graduates to be perceived as employable outside of the tourism industry or producing highly-skilled graduates for specialist positions in the tourism industry. Another set of gaps could result from misperception (pre-internship expectations) program (Zopiatis and Theocharous, 2013) of students in relation to the tourism industry idealizing or misperceiving relations existing between employees and employers and business models existing in tourism. (Pang, 2010) Internship programs should persuade students to stay in tourism industry and to enable them easier employment after graduation. (Chen and Shen, 2012) After the internship, students may create negative perception related to the tourism industry and to avoid further employment in tourism and hospitality industry, which is quite often case (Yafang and Gongyong, 2008; Lam and Ching, 2007; Chen and Shen, 2012) or to persevere in their desires and strive for managerial positions. In order to overcome this possible gap internship program planning (Mekawy and Abu Bakr, 2014; Chen and Shen, 2012) is of the crucial importance for positive perceptions of the students about internship and tourism and hospitality industry. In internship program planning process tourism industry should be involved together with educational institutions and internship performance should be evaluated from the perspective of each stakeholder involved in internship execution. (Chen and Shen, 2012) When it comes to inclusion of students into internship programs planning several problems are identified among two emerges as most important: how to conciliate role and responsibilities of a student as a student and as a planner of internship program and students' perception of adequate internship period. (Mekawy and Abu Bakr, 2014)

Most of the authors agree that internship represents a chance to minimize or totally remove the gap between theoretical knowledge and practice. (Zopiatis and Theocharous, 2013; Yafang and Gongyong, 2008; Mekawy and Abu Bakr, 2014; Pang, 2010; Sevillia et al., 2014; Donina and Luka, 2014; Lam and Ching, 2007) Whether they (stakeholders included in internship programs) will succeed in averting it depends on the perceptions of students towards internship. Several studies were conducted in relation to students' perception of internship. One of the most interesting studies was one by Lam and Ching (2007) among 307 students of tourism and hospitality schools and colleges in Hong Kong. Depending on institution their internship lasted from 3 to over 12 months and majority of respondents were female students (63.8\%). In this study they measured students' expectation prior to internship and their perceptions after the internship on 27 internship variables. Problem with this approach was in recollection of students after the internship what they expectations for each variable before internship were. This study showed that students' perceptions about internship were lower than their expectations before internship started. Similar study was conducted in Turkey by Koc et al. (2014) about expectations before and perceptions of the students after the internship. This study was performed on 603 students who participated in 15 different internship programs. This study showed that expectations and perceptions of the students were incoherent and that approximately $18 \%$ of students do not wish to pursue their career in tourism and hospitality industry after the internship experiences. Comprehensive study about students' perceptions about students' readiness for internship, the role of internship supervisor, gained benefits during the internship, internship perceived success and future intention to pursue a hospitality career was conducted by Zopiatis 
and Theocharous (2013). 166 students from Cyprus who have participated in at least one supervised internship experience were included in this study. The results of this study shows strong correlation between perception of perceived benefits during the internship and level of positive students' experiences and overall satisfaction with the internship. One more study was by Yafang and Gongyong (2008) measuring students' satisfaction towards their internship experience conducted among 124 students of tourism and hospitality schools in Hangzhou in China. The study involved 24 internship variables covering perceptions or satisfaction of students related to "job itself", "supervisor", "training and development", "pay and welfare" and "peer relationship".

\section{Research metodology}

For research purposes a questionnaire was created and distributed among students of the final year of the College of Tourism. As explained earlier, several models of students' perception of the importance and performances of internship programs during education for tourism industry were created, but we produced for this research new, adjusted model. This model takes in consideration students' perspectives about value and performances of internship programs they have attended during their education in College of Tourism.

The questionnaire created for this research consists of two parts. The first part of the questionnaire relates to the socio-demographic profile and socio-demographic characteristics of respondents. The second part has 11 variables or determinants of which 4 are related to students' perception of necessity and professional advantages of internship programs, another 4 are related to process if internship and cooperation between students and employers, 2 attributes are related to communication between students and College and coherence between theoretical knowledge and practical skills they have learned during internship. And fi- nally, $11^{\text {th }}$ attribute is about students' overall satisfaction with the internship.

For the questionnaire is very important to determine its reliability or internal consistency. Reliability test determines the consistencies of the results obtained through the test and ensure that the use of different items in the measurement of various constructions delivers consistent results. In theory, more than one method is used for determining the reliability of test such as re-testing when the test is repeated after a certain time and its results are compared with the results of the first test, then the methods of parallel test forms and methods of internal consistency. For the purpose of this research was used method of internal consistency within which we used different techniques among which the most used are split-half Reliability Coefficient, Kuder-Richardson Formula, and Cronbach Coefficient Alpha. Kuder-Richardson formula is used for the tests containing questions with two possible answers, while split-half Reliability Coefficient is conducted by treating a test as two tests dividing the issues into two subsets. ${ }^{1}$

However, one of the most popular statistical techniques in determining the reliability of the test is Cronbach Coefficient Alpha which determines internal consistency or average correlation of items in the survey in order to assess reliability. It is used for surveys with questions with two possible answers and for tests with value-answers (using Likert scale with common values of scale from 1 to 5). The value of the Cronbach Coefficient Alpha is in the range 0 to 1 and the higher the obtained value is the test is more reliable. Generally accepted reliability limit of the test is $\geq 0,70$, but in some cases lower values of Cronbach Alpha were accepted $(\geq 0,50$ or $\geq 0,60)$. (Reynaldo, Santos,

1 More about mentioned methods you can find at www.experiment-resources.com/ internal-consistency-reliability.html and www. creative-wisdom.com/teaching/assessment/ alpha.html. 
1999; Qu et al., 2000; www.ats.ucla.edu/stat/ spss/faq/alpha.html)

In this research for the assessment of attributes was used Likert scale with values from 1 to 5 for each attribute in form of confirmative statement. ${ }^{2}$ This is why we used Cronbach Coefficient Alpha for determining the reliability of the questionnaire which was confirmed since Cronbach Coefficient Alpha has value of .809 .

The questionnaire was distributed directly to the students and on this occasion 100 questionnaires were distributed. Of this number, 83 questionnaires were returned filled with 78 questionnaires filled in completely and for the processing we took into account only those completely filled. This way we achieved response rate of $78 \%$ and approximately $25 \%$ of all students of the final year participated in this survey. Thus, the sample size is quite satisfactory and we can say that the sample is representative.

\section{Characteristics of respondents}

When it comes to characteristics of respondents into consideration were taken following characteristics: gender, occupation (place of employment) and type of company or organization where students had internship.

Table 1. Characteristics of respondents

\begin{tabular}{lcc}
\hline Characteristics & $\begin{array}{c}\text { Absolute frequen- } \\
\text { cies }\end{array}$ & \% \\
\hline Gender & 16 & 20.51 \\
\hline Male & 54 & 69.23 \\
Female & 8 & 10.26 \\
Unanswered & & 82.05 \\
\hline Occupation & 64 & 6.41 \\
\hline Unemployed & 5 & 10.26 \\
Employed in companies and organizations related to & 8 & 1.28 \\
tourism & 1 & \\
Employed in company unrelated to tourism & & 47.44 \\
Employed in public sector & 37 & 15.38 \\
\hline Company or organization of internship & 12 & 5.13 \\
\hline Travel agency/tour operator & 4 & 29.49 \\
Hotel & 23 & 2.56 \\
DMO or Convention bureau & 2 &
\end{tabular}

Source: Data analysis

2 Value 1=strong disagreement with the statement, Value 2=partial disagreement with the statement, Value $3=$ neutral attitude, Value 4=partial agreement with the statement and Value 5=strong agreement with the statement. 
As it can be seen in Table 1, eight of the respondents didn't stated their gender but their answers were taken into account because it can not affect final results considering students' perception of internship they attended to. Majority or almost $70 \%$ of respondents were females and it is in coherence with the gender structure of the student population at the College of Tourism. Students are mainly unemployed (82.05\%) and only 5 respondents are employed within tourism industry. Taking this fact in consideration, student internship program is of the most importance for the students as a way to learn and acquire skills requested for their future jobs.

When it comes to company or organization where internship programs were undertaken majority of respondents had their internship in travel agencies/tour operators and hotels, 49 respondents or $62.82 \%$ and another 23 respondents (29.49\%) had their internship in more than one type of company or organization (travel agencies, tour operators, hotels and DMO and convention bureaus etc.).

\section{Descriptive statistics}

For the purpose of this paper with descriptive statistical analysis will be covered the arithmetic mean and standard deviation. Usually mode and median are standard parts of descriptive statistics but there is no need to show them regarding this research. The arithmetic mean belongs to central tendency measures used to display the results in factorial designs. Central tendency measures describe phenomena, i.e. ways in which the values of respondents on variables are grouped around the average and scatter around. As the name suggests, the aim is to determine the center of the basic set.

The arithmetic mean is the most commonly used measure of central tendency and represents the average of all the results or the number which expresses the value around which values of all respondents in one variable are grouped. Often, it is referred to as average or mean value. This measure is obtained by the aggregate value and divided by the number of values. It is calculated using the formula:

$$
\mathrm{M}=\sum \mathrm{x} / \mathrm{N}
$$

where $\mathrm{M}$ is the arithmetic mean, $\Sigma \mathrm{x}$ represents the sum of the individual values of $\mathrm{x}$ (the sum of the results) and $\mathrm{N}$ is the total number of results.

Standard deviation is not central tendencies measure but measure of variations or deviations. It tells us how much the average set of elements deviate from the arithmetic mean of the sample, in another words the standard deviation of the sample tells us average deviation of sample elements from the arithmetic mean of the sample. The greater value of standard deviation is the deviation is higher, and vice versa. It is calculated by the following formula:

$$
\sigma=\sqrt{\frac{\sum \mathrm{x}^{2}}{\mathrm{~N}}}
$$

where $\sigma$ is the standard deviation, $\Sigma$ represents the sum, $\mathrm{x}$ is the deviation of each individual results from the mean and $\mathrm{N}$ is the total number of measurements or subjects. 
Table 2. Mean and standard deviation for analyzed variables

\begin{tabular}{|c|c|c|c|}
\hline Variables & $\mathrm{N}$ & Mean & $\begin{array}{l}\text { Std. Devia- } \\
\quad \text { tion }\end{array}$ \\
\hline $\begin{array}{l}\text { I think that the internship program is an essential part of the } \\
\text { learning process }\end{array}$ & 78 & 4.92 & .268 \\
\hline During the studies I was interested in internship program & 78 & 4.53 & .716 \\
\hline $\begin{array}{l}\text { Performing internship influenced the improvement of my ré- } \\
\text { sumé/biography }\end{array}$ & 78 & 4.09 & 1.130 \\
\hline $\begin{array}{l}\text { Performing internship influenced the acquisition of new knowl- } \\
\text { edge and practical skills in the area I am studying for }\end{array}$ & 78 & 4.22 & 1.124 \\
\hline $\begin{array}{l}\text { Cooperation with the employer during internship has been } \\
\text { satisfactory }\end{array}$ & 78 & 3.94 & 1.121 \\
\hline $\begin{array}{l}\text { After completion of internship I remained in contact with the } \\
\text { employer for possible future employment }\end{array}$ & 78 & 3.04 & 1.490 \\
\hline $\begin{array}{l}\text { The duration of internship is long enough to acquire necessary } \\
\text { knowledge and skills }\end{array}$ & 78 & 3.53 & 1.102 \\
\hline I felt as a team member during internship & 78 & 3.62 & 1.176 \\
\hline $\begin{array}{l}\text { Internship is in line with the theoretical knowledge acquired } \\
\text { during studies }\end{array}$ & 78 & 3.36 & 1.057 \\
\hline $\begin{array}{l}\text { Communication with the College concerning the internship was } \\
\text { at satisfactory level. }\end{array}$ & 78 & 3.53 & 1.016 \\
\hline Internship completely fulfilled my expectations & 78 & 3.56 & 1.305 \\
\hline Valid N (listwise) & 78 & & \\
\hline
\end{tabular}

Source: Data analysis

As shown in Table 2 mean values for all 11 variables are in range from 3.04 for "staying in contact with an employer after internship was finished" to 4.92 for "students' perception of necessity of internship as integral part of learning process". Also, students" "interest in internship" (4.53), "acquiring of knew knowledge and practical skills through internship" (4.22) and "influence of internship on improvement of students' biographies" (4.09) are variables with very high mean values. Beside "contact with an employer after internship" lowest mean values of 3.36 has "students' perception of coherence between theoretical knowledge acquired during studies and internship". All other variables have mean value over 3.50 which could be considered as satisfactory or very satisfactory. Overall "satisfaction of students with expectations considering internship" is 3.56. All variables with mean values over 3 are considered as positively rated variables, therefore students have positive perception about the role and importance of internship program as part of formal education.

When it comes to standard deviations there is strong agreement among students about "necessity of internship program as integral part of their formal education" and their "interest in internship", since these two variables have lowest standard deviations. Highest values of standard deviation have "contact with an employer after internship" and "overall satisfaction of students with expectations considering internship", thus there is medium to high disagreement among students about these two variables.

In order to check if there were any discrepancies between students based on their sex or place of internship, independent samples T-test was conducted. Independent samples T-test compares the differences between the means of two unrelated groups of 
respondents on the same dependant variable. So it will be determined whether there are differences between means of determi- nants according to the sex of respondents and place of internship.

Table 3. Independent samples T-test based on gender of respondents

\begin{tabular}{|c|c|c|c|c|c|}
\hline Determinant & Sex & M & $\sigma$ & $\mathrm{t}$ & Sig \\
\hline internship & Male & 3.7557 & .60043 & -.497 & .765 \\
\hline
\end{tabular}

$M=$ Mean, $\sigma=$ Standard deviation, $t=t$ statistic, Sig= significance value of the statistic

Confidence interval $=95 \%$

Source: Data analysis

Based on data from independent samples T-test based on gender of respondents, which are shown in Table 3, the assumption that there are no significant differences among the students of different sex in the evaluation of the role and importance of internship as part of formal education has been confirmed.

Table 4. Independent samples T-test based on place of internship

\begin{tabular}{|c|c|c|c|c|c|}
\hline Determinant & $\begin{array}{c}\text { Place of } \\
\text { internship }\end{array}$ & $\mathbf{M}$ & $\sigma$ & $\mathbf{t}$ & Sig \\
\hline \multirow{2}{*}{$\begin{array}{l}\text { The role and importance of intern- } \\
\text { ship as part of formal education }\end{array}$} & $\begin{array}{l}\text { Travel agency/ } \\
\text { tour operator }\end{array}$ & 3.8182 & .48485 & \multirow{2}{*}{-.645} & \multirow[t]{2}{*}{.138} \\
\hline & Hotel & 3.9790 & .66980 & & \\
\hline
\end{tabular}

$M=$ Mean, $\sigma=$ Standard deviation, $t=t$ statistic, Sig= significance value of the statistic

Confidence interval $=95 \%$

Source: Data analysis

Also, as shown in Table 4, when it comes to place of internship there are no significant differences between respondents and in this case the assumption is confirmed too. For the purposes of this paper, difference of mean values between students who had their internship in travel agencies/tour operators and those in hotels was tested since these two groups of students were the majority of the respondents.

\section{Conclusion}

Quality human resources are the basis of future development of service industries, including tourism. The need of the tourist industry for quality human resources is indisputable, especially because we are wit- nessing frequent and increasingly massive involvement of inadequate human resources in tourism as part of pursuit for profit which can result in dissatisfaction of guests in the already tense economic situation which currently exists in the world economy and some tourist destinations.

Adequate theoretical knowledge provided by higher education institutions in the world and Serbia represent only one part of overall knowledge and skills necessary for students to find a job after studies. Apart from theoretical knowledge practical skills and abilities are required in order to meet demands of tourism industry and tourists. Tourism industry is looking for employees prepared to immediately engage and become a part of service process, all that to prevent additional costs of training and employment 
of new workers and to reduce overall operating costs. This problem was recognized by higher education institutions and, in their teaching curriculum, has involved practical training or internship programs conducted by tourism enterprises under the supervision of tourism professionals and lecturers in charge of their internship. By including practical training or internship, particularly in vocational studies, students are offered assurance that they will poses all necessary knowledge and practical skills and abilities for employment at operational and managerial positions in tourism industry.

In this paper, a research was carried about perception of students of the College of tourism in relation to the role and importance of internship as part of formal education. Based on the results of the research it is possible to draw some important conclusions. Students of College of tourism are aware about the need of inclusion of internship as part of formal education and they show a significant interest in an internship during their studies. Also, students percept that internship has contributed to strengthening their résumé and that during internship they have acquired practical knowledge and skills useful for future employment. In addition, students are generally satisfied with the contact and treatment by an employer who has managed to make them a part of the team. However, most students failed to immediately achieve such a level of contact with employer to secure certain employment after the studies, which is somewhat understandable because tourism in Serbia is still insufficiently developed and demand for employees in the tourism industry have seasonal character. Overall impression of the students about internship is satisfactory and positive, but there is a space for further improvement of this impression.

We can conclude that perceived differences between theoretical knowledge and practical skills acquired during internship are somewhat expected. These differences are probably the result of the curriculum which educates students for managers in tourism and during internship they were mainly engaged in operational activities. Operative skills acquired during internship are significant addition to theoretical knowledge and vice versa, and that will allow students a comprehensive understanding of business in tourism and adequately prepare them for possible managerial positions. However, because determining the cause of disagreements in the perception of the students considering this particular problem was not specific subject of this research it would be needed to conduct more detailed research in the future. It can be concluded that overall research results are in line with similar surveys conducted in World about students' perceptions of internship and its role during education for tourism.

\section{Literature}

Amoah V.A. \& Baum T. (1997). Tourism education: policy versus practice, International Journal of Contemporary Hospitality Management, 9(1), 5-12.

Chen T.L. \& Shen C.C. (2012). Today's intern, tomorrow's practitioner?-The influence of internship programmes on students' career development in the Hospitality Industry, Journal of Hospitality, Leisure, Sport \& Tourism Education 11, 29-40.

Dale C. \& Robinson N. (2001). The theming of tourism education: a three-domain approach, International Journal of Contemporary Hospitality Management, 13(1), 30-34.

Donina A. \& Luka I. (2014). The compliance of tourism education with industry need in Latvia, European Journal of Tourism, Hospitality and Recreation, Special Issue, 303-330.

Hjalager, A-M. (2003). Global Tourism Careers: Opportunities and Dilemmas Facing Higher Education in Tourism, Journal of Hospitality, Leisure, Sport and Tourism Education 2(2), 26-38. 
Horng-Huey P. \& Mojdeh J. (2014). Practical Learning in Tourism Education: A Hands-on Bidding and Planning Practice, Journal of Education and Practice, 5(13), 35-41.

Hughes K., Mylonas A. \& Benckendorff P. (2013). Students' reflections on industry placement: Comparing four undergraduate work-integrated learning streams, Asia-Pacific Journal of Cooperative Education, 14(4), 265-279.

Juran J., Godfrey M. \& Blanton A. (1999). Managing Human Resources and Quality, McGraw-Hill/Professional Book, Columbus.

Koc E., Yumusak S., Ulukoy M., Kilic R. \& Toptas A. (2014). Are internship programs encouraging or discouraging?-A viewpoint of tourism and hospitality students in Turkey, Journal of Hospitality, Leisure, Sport \& Tourism Education 15, 135-142.

Lam T. \& Ching L. (2007). An exploratory study of an internship program:The case of Hong Kong students, Hospitality Management 26, 336-351.

Lam T. \& Xiao H. (2000). Challenges and constraints of hospitality and tourism education in China, International Journal of Contemporary Hospitality Management, 12(5), 291-295.

Mekawy M.A. \& Abu Bakr M.A. (2014). Planning internship programs: Tourism students' perceptions, Tourism, 62(1), 41-61.

Pang J.M. (2010). Perceptions of the tourism and hospitality industry by Singapore polytechnic hospitality students: An exploratory study, UNLV Theses/Dissertations/Professional Papers/Capstones. Paper 700.

Qu H., Li L., Chu G.K.T. (2000): The comparative analysis of Hong Kong as an international conference destination in Southeast Asia, Tourism Management 21, 643-648.
Reynaldo J., Santos A. (1999): Cronbach's Alpha: A Tool for Assessing the Reliability of Scales, Journal of Extension, 37 (2).

Ruhanen L., Robinson R. \& Breakey N. (2013). A tourism immersion internship: Student expectations, experiences and satisfaction, Journal of Hospitality, Leisure, Sport \& Tourism Education 13, 60-69.

Sevillia S.F., Lhea C.R., Jourell E. \& Sumanga Dexter R. B. (2014). Internship Performance of Tourism and Hospitality Students: Inputs to Improve Internship Program, International Journal of Academic Research in Business and Social Sciences, 4(6), 42-53.

Spowart, J. (2011). Hospitality students' competencies: Are they work ready? Journal of Human Resources in Hospitality and Tourism, 10, 169-181.

Štetić S. \& Šimičević D. (2013). Značaj dodatne edukacije studenata Visoke turističke škole za hotelsko poslovanje na Micros Fidelio programskim rešenjima, Cogress Proceedings - Contemporary Trends in the Hospitality Industry, Hotelplan 2013., 487-494.

Yafang, B. \& Gongyong, F. (2008). A study on hospitality students' satisfaction towards their internship: a case from Hangzhou, China. School of Tourism and Health Zhejiang Forestry University. Retrieved January 20, 2016 from http:// www.seiofbluemountain.com/upload/ product/200910/2008glhy12a2.pdf.

Zopiatis A. \& Theocharous A.L. (2013). Revisiting hospitality internship practices: A holistic investigation, Journal of Hospitality, Leisure, Sport \& Tourism Education 13, 33-46.

https://explorable.com/internal-consistency-reliability (20.01.2016.)

www.ats.ucla.edu/stat/spss/faq/alpha.html (20.01.2016.)

www.creative-wisdom.com/teaching/assessment/alpha.html (20.01.2016.) 